\title{
Editorial: In for a Penny
}

A Dictionary of Philosophical Quotations is a successful first instance of a new genre invented by A. J. Ayer, on whose death in 1989 the work was continued by Jane O'Grady. The book is now published by Blackwell at $£ 19.99$. The editors have been helped by about fifty 'contributors' who are not, as one might expect, authors of the sentences and passages printed in the Dictionary. Some of those who are listed as 'major contributors' nevertheless make no contribution to the contents of the work: Casimir Lewy, David Pears, George Pitcher, Patrick Gardiner.

Jane O'Grady is conscious that the book would have been somewhat different in style and content if Ayer had lived to complete it:

I doubt whether he would have included as much from Derrida or from other Continental philosophicals as I have, being inclined to dismiss that style of philosophy as 'woolly uplift'. In fact, according to the limits he put on respectable philosophy in Language, Truth and Logic, many of these quotations would not merit inclusion at all, although he later recanted much of what he said in this young man's book.

Ms O'Grady takes us further into her confidence about the problems of selection:

To reproduce too many long closely argued passages runs the risk of boring the reader; to produce only the conclusions to such arguments would be baffling and frustrating; and it is often misleading, distorting, or impossible to convey an argument in small chunks or in passages full of ellipses. Or where this can be done, there is the danger of imposing a certain homogeneousness of quotability, and of replacing ponderousness with pithiness at the cost of losing philosophers' distinctiveness and style. Merely to reproduce their peripheral witticisms would not do justice to them either.

Perhaps she could have afforded to give us more 'one-liners' than she has actually chosen. Most of those presented are smothered by the long passages of the late and great philosophers: Plato, Aristotle, Descartes, Kant, Hegel, Wittgenstein, Russell. A highly quotable new one is by Myles Burnyeat: 'Plato is the model philosopher for those who value integrity above solutions'. There is a page of sayings of Oscar Wilde, and a handful of items from Dr Johnson, but there is not otherwise much representation of the work of 'non-philosophers'. 


\section{Editorial}

The project is altogether welcome, not least because it will be copied with variations, and so continue to provide entertainment and instruction. In the present inaugural product, the collections of some of the passages of the greater philosophers amount to useful introductions to their work. There is a serviceable glossary of philosophical terms.

A minor qualm about the price: the book is good value at $£ 19.99$. It would be equally good value at $£ 20.00$, a figure which would exonerate the publisher from the accusation of trying to induce philosophers to think that the price is $£ 19.00$ not $£ 20.00$. 